\title{
CHARACTERIZATION OF PREDICTED BACTERIAL COLD-ADAPTED LIPASE FROM SEAFOOD COLD STORAGE
}

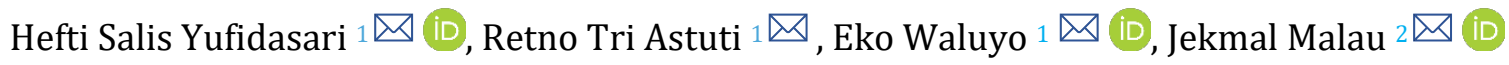 \\ ${ }^{1}$ Faculty of Fisheries and Marine Science, Universitas Brawijaya, Malang, 553512, Indonesia. \\ ${ }^{2}$ PT Sciencewerke, West Jakarta, 11480, Indonesia.
}

Received 5 November 2021

Accepted 16 December2021

Published 31 December2021

\section{CorrespondingAuthor \\ Hefti Salis Yufidasari, \\ hefti_salis@ub.ac.id \\ DOI \\ 10.29121/granthaalayah.v9.i12.2021 .4443}

Funding: This research was supported by the Institution of Research and Community Service (LPPM) Universitas Brawijaya through Hibah Peneliti Pemula 2020 (HPP 2020).

Copyright: (C) 2021 The Author(s). This is an open access article distributed under the terms of the Creative Commons Attribution License, which permits unrestricted use, distribution, and reproduction in any medium, provided the original author and source are credited.

\section{ABSTRACT}

Lipases constitute as top three most important group of enzymes along with carbohydrases and proteases, and are widely used in various industries. In particular, lipase that perform high activity at low temperatures, or referred as cold adapted lipase (CLPs) considered as attractive catalyst due to its activity at low temperature. This unique feature is the main advantage of cold adapted lipase utilization because it requires a low energy source that is correlated with lower production costs and energy. In addition, reactions occur in cold temperatures may result in better product quality. The purpose of this research was to perform screening and characterization of bacterial cold adapted lipase from seafood cold storage. Among 53 isolates, Kr_16_30, TI_37_14 and Kr_16_28 showed the highest activity with $4.12 \mathrm{U} / \mathrm{mL}: 3.87 \mathrm{U} / \mathrm{mL}$ and $3.21 \mathrm{U} / \mathrm{mL}$, respectively. Isolates $\mathrm{Kr} \_16 \_30$ seemed to be typical cold adapted lipase with optimum temperature at $20^{\circ} \mathrm{C}$ and $\mathrm{pH}$ 7. Isolates $\mathrm{Kr}_{-} 16 \_28$ performed highest lipolytic activity at $30^{\circ} \mathrm{C}$ while TI_37_14 suspected to be similar to typical mesophilic lipase with optimum temperature at $40^{\circ} \mathrm{C}$. Species identification based on sequencing of gene encoding $16 \mathrm{~s}$ rRNA revealed that isolates $\mathrm{Kr}_{-} 1630$ and $\mathrm{Kr}_{-} 1628$ are belong to genus Pseudomonas and Bacillus, repectively.

Keywords: Bacteria, Cold-Adapted Lipase, Characterization, Fish Cold Storage

\section{INTRODUCTION}

In recent decades, enzymes have received great attention in the effort to reduce chemical-based reactions in industrial process. Enzyme-mediated reactions are considered environmentally friendly. It produces less waste, require less energy, reduce the risk of pollution and potentially improve product quality Kavitha (2016) . Lipase (acyl glycerol hydrolases, EC 3.1.1.3) is one of most important enzymes with a wide range of applications in biotechnology, food, chemical, pharmaceutical, biodiesel and other industrial fields. Lipases are able to catalyze both the hydrolysis and the synthesis of esters from glycerol and long-chain fatty acids Jaeger and Eggert (2002) .

One of the main focus in enzyme development is the activity under extreme conditions Santiago et al. (2016). Temperature seemed to be one of the most crucial environmental factors in enzymatic reactions. Higher temperatures, which is often applied to industrial processes, will increase the rate of reaction, but also accelerate the deactivation of enzymes. Heat-resistant enzymes (thermophiles) can be used to solve this problem. However, reactions at high temperatures will increase production costs Cowan (2010). 
While thermophilic enzymes play an important role in reactions involving high temperatures, exploration of enzymes that are active at low temperatures gained more interest as its ability to promote reaction under mild condition Feller (2010). This group of lipases referred as cold adapted lipases (CLPs) or cold active lipase. These enzymes displayed great and efficient activity at low temperatures, leading to significant energy savings. For some applications, cold-adapted enzymes also maintain some fragile compounds from being damaged by higher temperatures Collins et al. (2012), Georlette et al. (2004). Therefore, they become an attractive choice to be applied in pharmaceuticals products, food, environmental bioremidiation and detergent ingredients Joseph et al. (2008) .

Microorganisms that grow in cold environments are good candidates to produce cold-adapted enzymes. They may develop special adaptations to support their metabolism and growth in those extreme condition. Compared to its exploration in extreme high or moderate temperature, the study of lipase producing bacteria in cold environment is relatively limited.

The studies on cold adapted lypolitic enzyme generally come from psychrophilic environments or psychrophilic microorganisms isolated from polar and Antarctic regions, for example from genus Moraxella Feller et al. (1991), Psychrobacter Kulakova et al. (2004), Xuezheng et al. (2010) and Pseudomonas Zhang and Zeng (2008) as well as deep sea areas and food storage at low temperatures Dieckelmann et al. (1998), Domínguez De María et al. (2005). Polar region and constantly extreme temperature places are very potential as cold lipase source. However, in many cases, the enzymes are unstable even at moderate temperatures Joseph et al. (2008). Several cold adapted lipases obtained from the tropics area showed better thermal stability than those obtained from the alpine regions Kavitha and Shanthi (2013) .

Harnessing enzyme-based reaction largely depends on the bacterial genetics and optimum condition to ensuring the optimum activity. This study attempted to evaluate the potential bacteria producing cold adapted lipase from seafood cold storage. This work including screening, identification and initial characteriation to determine optimal conditions for better lipolytic activity.

\section{MATERIALS AND METHODS}

\section{Screening for Lipase-Producing Bacteria}

Clams, fish egg and crab meat samples were obtained from three cold storage at a modern supermarket in Malang City, East Java, Indonesia. A total 1 gram of sample was crushed and added by $50 \mathrm{~mL}$ of Basal Salt Solution (BSM) and incubated at $25^{\circ} \mathrm{C}$ for 48 hours. The mixture was diluted in a serial dilution calculation using $0.9 \% \mathrm{NaCl}$. Aliquots of $10-5$ to $10-9$ were inoculated on agar media containing $5 \mathrm{~g} / \mathrm{L}$ tryptone, $2.5 \mathrm{~g} / \mathrm{L}$ yeast extract, $9 \mathrm{~g} / \mathrm{L}$ agar with $1 \%$ Tween 20 or Tween 80 added as initial lipolytic screening. Incubation was carried out for $2-10$ days at $16^{\circ} \mathrm{C}, 25^{\circ} \mathrm{C}$ and $37^{\circ} \mathrm{C}$, respectively. Lipolytic activity is characterized by the appearance of white precipitation around the bacterial colonies. In order to collecting lipolytic bacteria, colonies growing with white precipitation sign were taken for further screening to validate their lipolytic activity.

Each bacterial colony was taken and separately inoculated by spotting on Sierra's Medium (10 g/L peptone, $5 \mathrm{~g} / \mathrm{L} \mathrm{NaCl}, 20 \mathrm{~g} / \mathrm{L}$ agar, $0.1 \mathrm{~g} / \mathrm{L} \mathrm{CaCl} 2$, and $1 \%$ Tween 80 or Tween 20 as lase substrates). Incubation was carried out at three different temperatures $\left(16^{\circ} \mathrm{C}, 25^{\circ} \mathrm{C}\right.$ and $\left.37^{\circ} \mathrm{C}\right)$ for 2-6 days Mukesh et al. (2012) . Lipolytic activity is characterized by the appearance of white precipitation around the bacterial colonies. Three potential bacterial isolates that showed largest 
precipitation zone were selected and re-grown on agar medium using the streak plate method to obtain a single colony.

\section{Production of Lipase Crude Extract}

Potential bacterial isolates were inoculated separately into $10 \mathrm{~mL}$ of broth medium containing $1 \%$ tryptone, $1 \%$ sodium chloride, $0.5 \%$ yeast extract and incubated for 24 hours with $150 \mathrm{rpm}$ agitation. The next day, 2\% culture was reinoculated in $50 \mathrm{~mL}$ of production medium containing 1\% tryptone, 1\% sodium chloride, $0.5 \%$ yeast extract and $1 \%$ lipase substrate. Incubation was carried out with agitation at $150 \mathrm{rpm}$ for $2 \times 24$ hours. The culture was centrifuged at $10,000 \mathrm{rpm}$ for 15 minutes. The supernatant was transferred into a sterile tube and referred to as the lipase crude extract.

\section{Activity of Lipase Crude Extract}

Lipase activity assay was carried out based on the method described by Stoytcheva et al. (2012) with slight modification of reaction mixture. A total of $2 \mathrm{~mL}$ of lipase substrate was added to reaction containing $2 \mathrm{~mL}$ of $0.1 \mathrm{M}$ sodium phosphate buffer $\mathrm{pH}$ 6.5: $2.5 \mathrm{ml}$ of distilled water, $0.5 \mathrm{ml}$ of $0.1 \mathrm{M} \mathrm{CaCl} 2$ and $1 \mathrm{ml}$ of crude extract. The reaction mixture was incubated with agitation at $150 \mathrm{rpm}$ for 15 minutes. The reaction was stopped by adding 96\% ethanol. Enzyme activity measured by titration method using $0.05 \mathrm{M} \mathrm{NaOH}$, with the addition of phenolphthalein as an indicator. One unit of crude extract lipase activity was defined as amount of enzyme required to produced $1 \mathrm{~mol}$ of fatty acid per minute under the measurement condition.

\section{Effect of Temperature and pH on Enzyme Activity}

Characterization of lipolytic activity were carried out at different temperature and $\mathrm{pH}$ condition. Determination of the optimum temperature was done by testing at various temperatures of $10^{\circ} \mathrm{C}, 20^{\circ} \mathrm{C}, 30^{\circ} \mathrm{C}, 40^{\circ} \mathrm{C}, 50^{\circ} \mathrm{C}, 60^{\circ} \mathrm{C}$ and $70^{\circ} \mathrm{C}$.

Optimal $\mathrm{pH}$ values were measured by incubation of crude extract at various different buffers with $\mathrm{pH}$ range from 5 to 11 . Buffer systems consist of $\mathrm{CH}_{3} \mathrm{COONa} / \mathrm{CH}_{3} \mathrm{COOH}$ (pH5), $\mathrm{KH}_{2} \mathrm{PO} 4 / \mathrm{Na}_{2} \mathrm{HPO} 4$ (pH6, 7); Tris $\mathrm{HCl}(\mathrm{pH} 8,9)$ and $\mathrm{Na}_{2} \mathrm{HPO} 4 / \mathrm{NaOH}$ (pH 10.11). Similar procedure is applied as the standard method. The lipolytic activity for each temperature and $\mathrm{pH}$ were converted into relative activity using the highest lipase activity as control (100\% of relative activity).

\section{Amplification of partial gene encoding 16s rRNA}

Potential isolates were subjected to species identification based on 16s rRNA sequence. The genomic DNA was isolated using wizard genomic DNA purification kit (Promega, USA). The concentration and purity of DNA was analyzed using nanodrop 2000 (Thermofisher Scientific, USA). Amplification of the 16s rDNA sequence was carried out using PCR with specific forward primer $63 \mathrm{~F}$ and reverse primer 1387R.

PCR mixture contained $1 \mu \mathrm{L}$ DNA genome, $5 \mu \mathrm{L}$ GoTaq Green Master Mix (Promega, USA), $1 \mu \mathrm{L}$ of each primer and nuclease free water up to $10 \mathrm{uL}$ final reaction. Verification was done by electrophoresis in $1 \%$ agarose gel $(\mathrm{w} / \mathrm{v})$. The PCR product was purified and injected into 3130 DNA analyzer machine (Applied Biosystems, Foster City, USA) following the official running protocol. After analyzing, NCBI-BLAST were performed to find the closest match of the contiguous sequence (https://www.ncbi.nlm.nih.gov/). 


\section{RESULTS AND DISCUSSIONS}

Lipase enzymes are naturally present in almost all living organism, including microorganism (such as bacteria and yeasts), plants and animals Gupta et al. (2004) . Lipase enzymes from microorganisms have important value in the industrial world because its convenience and production efficiency. Various studies focused on the exploration and use of lipases that are active at extreme temperatures, due to industrial processes that are mostly carried out at high temperatures. However, the use of high temperatures may not be very beneficial in terms of the energy and production cost. In addition, high temperature may affect the quality of fragile components in food or pharmaceuticals.

Therefore, the exploration of lipases that are active at cold temperatures or commonly referred to as cold-adapted lipases or cold-active lipases gained a lot of attention due to their activity under mild condition. Thus, significant study has been devoted to performing screening and characterization of cold adapted lipase from bacterial and fungal origins.

This present work aimed to obtain and determine the characteristics of lipase enzymes from clams, fish eggs and crab meats samples in cold storage. Total bacteria were grown on non-selective Plate Count Agar medium. Tween 20 and Tween 80 were added into the medium for initial screening and make it easier to selecting the candidate of lipase producing colony for further screening. Incubation was carried out at three different temperatures, which is $16^{\circ} \mathrm{C}, 25^{\circ} \mathrm{C}$ and $37^{\circ} \mathrm{C}$.
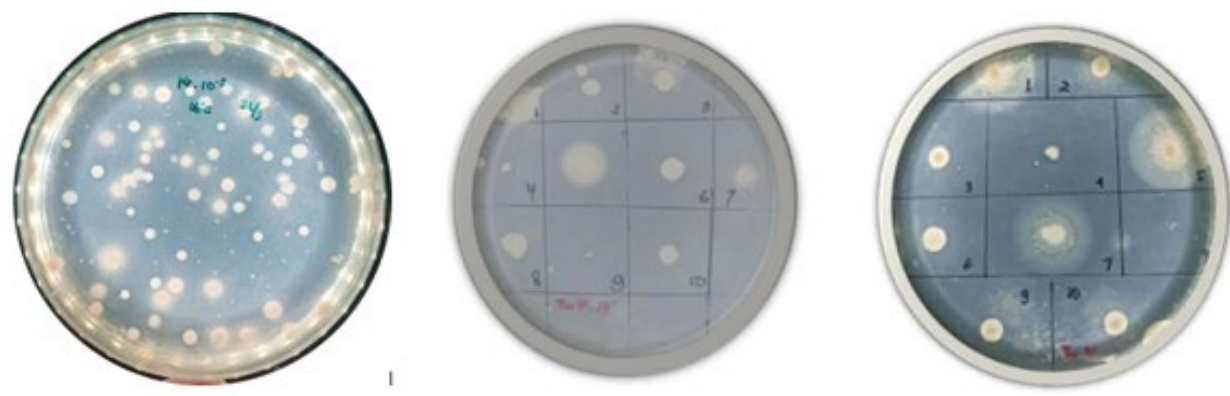

Figure 1 The growth of total bacteria on PCA medium added with Tween 80 (A), the lipolytic activity at Sierra's Medium containing Tween 20 (B) and Tween 80 (C). The white presipitation around the colony indicating lipolytic activity

The incubation time required for bacterial growth turn out to be significantly different for each temperature od incubation, around 18 hours $\left(37^{\circ} \mathrm{C}\right), 24-48$ hours $\left(25^{\circ} \mathrm{C}\right)$ and 7 days $\left(16^{\circ} \mathrm{C}\right)$ incubation temperatures, respectively. Clams, fish eggs and crab meat samples from modern market in Malang city, contained bacteria with varying amounts from $6,27 \times 105$ up to $1.23 \times 107$. Bacterial colonies with white presipitation were selected and re- inoculated separately on Sierra's Medium as validation of lipolytic avtivity Figure 1.

Table 1 Total isolated bacteria and the persentage of lipase producing bacteri from each sample and temperature of incubation

\begin{tabular}{|ccc|}
\hline SampleID, temperature & Isolated bacteria & Lipolytic bacteria \\
Clam, $16^{\circ} \mathrm{C}$ & 32 & $15(46.88 \%)$ \\
$\mathrm{Clam}, 25^{\circ} \mathrm{C}$ & 10 & $5(50 \%)$ \\
$\mathrm{Clam}, 37^{\circ} \mathrm{C}$ & 14 & $8(57.14 \%)$ \\
\hline
\end{tabular}




$\begin{array}{ccc}\text { Fish egg, } 16^{\circ} \mathrm{C} & 5 & 1(20 \%) \\ \text { Fish egg, } 25^{\circ} \mathrm{C} & 9 & 2(22.22 \%) \\ \text { Fish egg, } 37^{\circ} \mathrm{C} & 12 & 9(75 \%) \\ \text { Crab meat, } 16^{\circ} \mathrm{C} & 9 & 3(33.33 \%) \\ \text { Crab meat, } 25^{\circ} \mathrm{C} & 10 & 6(60 \%) \\ \text { Crab meat, } 37^{\circ} \mathrm{C} & 7 & 4(57.14)\end{array}$

Lipolytic activity assay using Tween 20 or 80 based on the principle of calcium salt precipitation. Hydrolysis of tween releases fatty acids which bind to calcium derived from $\mathrm{CaCl}_{2} \cdot 2 \mathrm{H}_{2} \mathrm{O}$ in the medium. This complex will form insoluble crystals, appear as white precipitation around the colony (Figure $2 \mathrm{~B}, \mathrm{C}$ ), as indication that the bacterial colony produces extracellular lipase Rai et al. (2014).

\begin{tabular}{|cc|}
\hline Table 2 Lipolytic activity of three most potential bacteria \\
\hline Isolate & Lipase Activity \\
\hline Kr_16_30 & $4.12(\mathrm{U} / \mathrm{mL})$ \\
\hline TI_37_14 & $3.87(\mathrm{U} / \mathrm{mL})$ \\
\hline Kr_16_28 & $3.21(\mathrm{U} / \mathrm{mL})$ \\
\hline
\end{tabular}

Bacteria isolated from fish egg at $16^{\circ} \mathrm{C}$ incubation temperature showed the highest percentage of lipolytic bacteria (75\%). Among all bacterial, isolates Kr_16_30, TI_37_14 and Kr_16_28 showed the largest precipitation zone Table 2. Thus, the three isolates were considered potential and used for further analysis.

The culture of three potential bacteria were prepared using broth medium containing Tween 80. The cell free supernatants are measured to determine the extracellular lipase activity. Isolate Kr_16_30 turn out to be the most potential lipase producer with the activity values presented in Table 2 . The production of lipase enzymes by psychotropic organisms varies among the species, which is also influenced by the optimum temperature, $\mathrm{pH}$ and specificity of the enzyme.

After incubation at various temperatures, the optimum temperature of isolate $\mathrm{Kr} \_16 \_30$ was observed at $20^{\circ} \mathrm{C}$, with lipolytic activity slightly higher than its activity measured at $16^{\circ} \mathrm{C}$ Figure 2 . At higher temperature, enzyme activity decreased to less than $80 \%$ at $30^{\circ} \mathrm{C}$ and about $50 \%$ activity remaining at $50^{\circ} \mathrm{C}$.

Isolates TI_37_14 and $\mathrm{Kr} \_16 \_28$ had optimum activity at $40^{\circ} \mathrm{C}$ and $30^{\circ} \mathrm{C}$, respectively. Isolate $\mathrm{Kr} \_16 \_28$ appeared to have a relatively stable lipolytic activity in the temperature range $20^{\circ} \mathrm{C}$ to $40^{\circ} \mathrm{C}$ with more than $80 \%$ of the maximum activity Figure 2. Lipase activity of all isolates are quite low at $10^{\circ} \mathrm{C}$. Only isolate $\mathrm{Kr} \_16 \_28$ was able to maintain its activity at more than half of the optimum temperature. Therefore, the lipase produced by Kr_16_30 seemed closer to typical cold adapted lipase, while lipolytic activity of isolates TI_37_14 is similar to most mesophilic bacterial lipase, in the respect of the optimum temperature condition. 

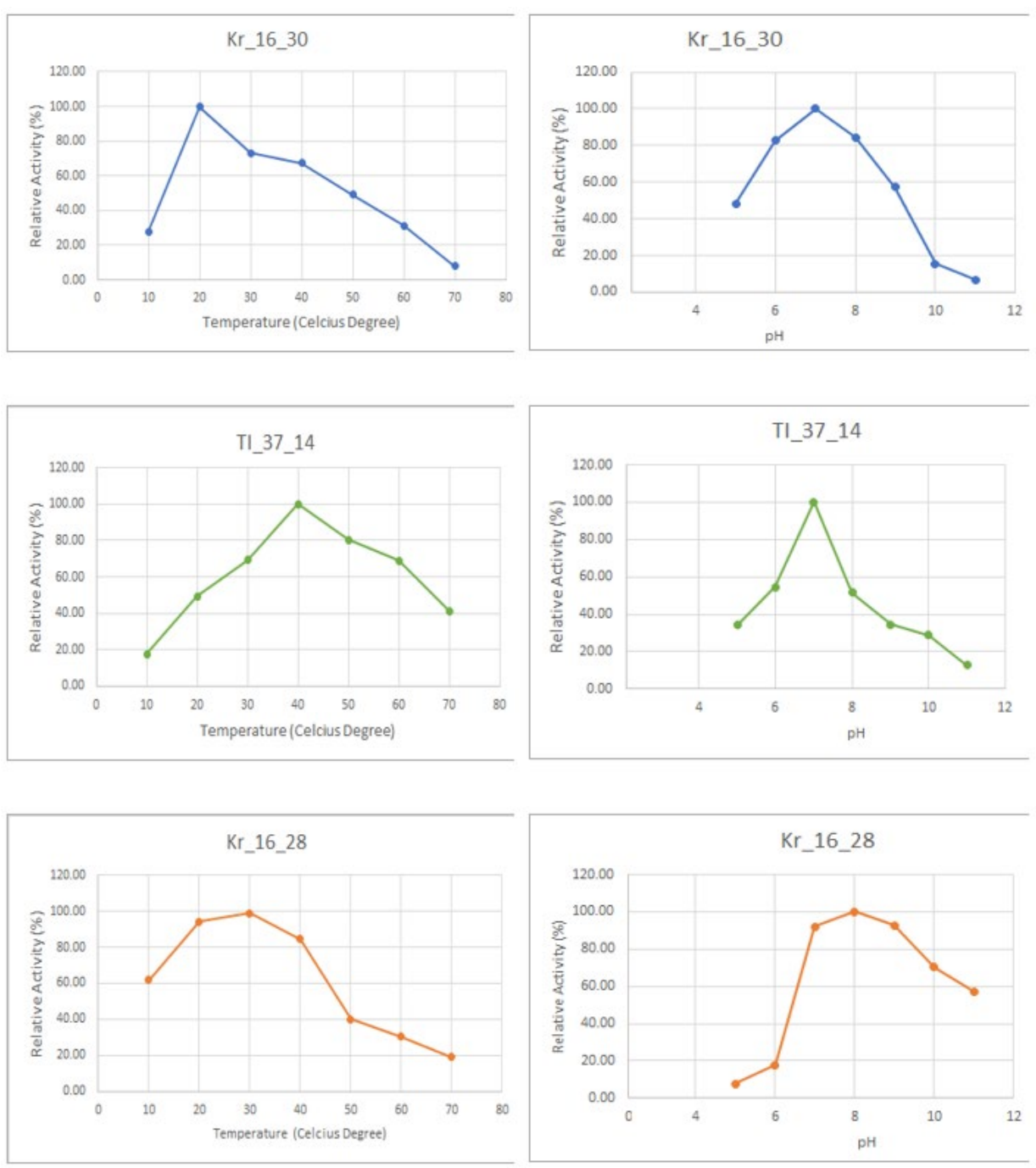

Figure 2 Lipolytic activity of lipase crude extract from potential bacteria under various temperature (left) and pH (right)

The $\mathrm{pH}$ value of 7 was determined as the optimum condition of isolates Kr_16_30 and TI_37_28 Figure 2. Isolate $\mathrm{Kr} \_16 \_30$ had fairly stable activity in the pH range of 6 to 8, while a sharp decrease was observed in isolate TI_37_28 in same pH value. Under alkaline treatment with $\mathrm{pH}$ value of 11 , the activities of isolates Kr_16_30 and TI_37_14 were measured to be $6.65 \%$ and $12.92 \%$, respectively.

Changes in pH value affected the lipolytic activity of isolate Kr_16_28 with a different pattern. The optimum $\mathrm{pH}$ was observed at $\mathrm{pH} 8$, with more than $90 \%$ activity at $\mathrm{pH}$ 9. The lipolytic activity of this isolate was sensitive to acidic conditions and was relatively maintained at alkaline temperatures with a remaining activity of $61.68 \%$ activity at $\mathrm{pH} 11$. The acidity of the media greatly affects various enzymatic processes and the transport of compounds across the cell membranes Kuddus and Ramteke (2008).

Table 3 Species identification of potential bacteria producing cold adapted lipase

\begin{tabular}{|ccccc|}
\hline $\begin{array}{c}\text { Sample } \\
\text { ID }\end{array}$ & Identified Bacteria by BLAST & $\begin{array}{c}\text { Query } \\
\text { Cover }\end{array}$ & $\begin{array}{c}\text { E } \\
\text { value }\end{array}$ & $\begin{array}{c}\text { Percent } \\
\text { Identity }\end{array}$ \\
\hline $\mathrm{Kr} \_16 \_30$ & Pseudomonas aeruginosa & $100 \%$ & 0 & $97.21 \%$ \\
\hline
\end{tabular}




\begin{tabular}{|c|c|c|c|c|}
\hline & $\begin{array}{l}\text { unculturable bacterium clone } \\
\text { ncd } 2191 \mathrm{~b}\end{array}$ & $100 \%$ & 0 & $97.21 \%$ \\
\hline & Pseudomonas Aeruginosa strain BGS1 & $100 \%$ & 0 & $97.10 \%$ \\
\hline Kr_16_28 & Bacillus velezensis strain IMJ11 & $100 \%$ & 0 & $99.90 \%$ \\
\hline & Bacillus siamensis strain ICMP 20282 & $100 \%$ & 0 & $99.90 \%$ \\
\hline & $\begin{array}{c}\text { Bacillus amyloliquefaciens strain GuBC- } \\
1\end{array}$ & $100 \%$ & 0 & $99.90 \%$ \\
\hline
\end{tabular}

In this study, the species identification of isolates TI_37_28 was not performed because its optimal activity was observed at temperature higher than $30^{\circ} \mathrm{C}$. The species identification of $\mathrm{Kr}_{-} 1630$ and $\mathrm{Kr} \_16 \_28$ performed by $16 \mathrm{~s}$ rRNA sequencing. BLAST results of amplified DNA sequences provided information that the two isolates were member of phylum Proteobacteria and Firmicutes. The fragment sequence of isolates $\mathrm{Kr} \_16 \_30$ described the highest similarity with Pseudomonas aeruginosa (97.21\% similarity, $100 \%$ query cover), unculturable bacterium clone ncd2191b (97.21\% similarity, 100\% query cover), and P. Aeruginosa strain BGS1 (97.10\% similarity, 100\% query cover). The isolate Kr_16_28 is part of the Genus Bacillus, with the highest similarity to Bacillus velezensis strain IMJ11 (99.90\% similarity, 100\% query cover), Bacillus siamensis strain ICMP 20282 (99.90\% similarity, $100 \%$ query cover) and Bacillus amyloliquefaciens strain GuBC-1 (99.90\% similarity, $100 \%$ query cover).

\section{CONCLUSIONS AND RECOMMENDATIONS}

A total of 53 lipolytic bacteria ware screened from clam, fish egg and crab meat samples collected from fish cold storage. Isolates $\mathrm{Kr} \_16 \_30, \mathrm{TI}$ _37_14 and Kr_16_28 showed the highest activity with $4.12 \mathrm{U} / \mathrm{mL}: 3.87 \mathrm{U} / \mathrm{mL}$ and $3.21 \mathrm{U} / \mathrm{mL}$, respectively. Isolates $\mathrm{Kr}_{-} 16 \_30$ seemed to be typical cold adapted lipase with optimum temperature at $20^{\circ} \mathrm{C}$ and $\mathrm{pH}$ 7. Isolates $\mathrm{Kr} \_16 \_28$ performed highest lipolytic activity at $30^{\circ} \mathrm{C}$ while TI_37_14 suspected to be similar as most mesophilic lipase with optimum temperature at $40^{\circ} \mathrm{C}$. Species identification based on sequencing of 16s rRNA revealed that isolates Kr_16 30 and Kr_16 28 are belong to genus Pseudomonas and Bacillus, respectively.

\section{ACKNOWLEDGEMENTS}

T This work was supported by the Institution of Research and Community Service (LPPM) Universitas Brawijaya through Hibah Peneliti Pemula 2020 (HPP 2020).

\section{REFERENCES}

Collins, T., Gerday, C., \& Meuwis, M. (2012) Cold-Adapted Enzymes.

Cowan, D. (2010) Concentration of Omega-3 Fatty Acids Using Enzymes. Agro FOOD industry hi-tech,

Dieckelmann, M., Johnson, L. A., \& Beacham, I. R. (1998) The diversity of lipases from psychrotrophic strains of pseudomonas : A novel lipase from a highly lipolytic strain of Pseudomonas fluorescens, Journal of Applied Microbiology, Vol. 85, No. 3, 527-536. Retrieved from https://doi.org/10.1046/j.1365-2672.1998.853530.x 
Domínguez De María, P., Carboni-Oerlemans, C., Tuin, B., Bargeman, G., Van Der Meer, A., \& Van Gemert, R. (2005) Biotechnological applications of Candida antarctica lipase A : State-of-the-art, Journal of Molecular Catalysis B : Enzymatic, Vol. 37, No. 1-6, 36-46. Retrieved from https://doi.org/10.1016/j.molcatb.2005.09.001

Feller, G. (2010) Protein stability and enzyme activity at extreme biological temperatures, Journal of Physics Condensed Matter, Vol. 22, No. 32, 1-17. Retrieved from https://doi.org/10.1088/0953-8984/22/32/323101

Feller, G., Thiry, M., Arpigny, J. L., \& Gerday, C. (1991) Cloning and expression in Escherichia coli of three lipase-encoding genes from the psychrotrophic antarctic strain Moraxella TA144. Gene, Vol. 102, No. 1, 111-115. Retrieved from https://doi.org/10.1016/0378-1119(91)90548-P

Georlette, D., Blaise, V., Collins, T., D'Amico, S., Gratia, E., Hoyoux, A., Marx, J. C., Sonan, G., Feller, G., \& Gerday, C. (2004) Some like it cold : Biocatalysis at low temperatures, FEMS Microbiology Reviews, Vol. 28, No. 1, 25-42. Retrieved from https://doi.org/10.1016/j.femsre.2003.07.003

Gupta, R., Gupta, N., \& Rathi, P. (2004) Bacterial lipases : An overview of production, purification and biochemical properties, Applied Microbiology and Biotechnology, Vol. 64, No. 6, 763-781. Retrieved from https://doi.org/10.1007/s00253-004-1568-8

Jaeger, K. E., \& Eggert, T. (2002) Lipases for biotechnology, Current Opinion in Biotechnology, Vol. 13, No. 4, 390-397. Retrieved from https://doi.org/10.1016/S0958-1669(02)00341-5

Joseph, B., Ramteke, P. W., \& Thomas, G. (2008) Cold active microbial lipases : Some hot issues and recent developments. Biotechnology Advances, Vol. 26, No. 5, 457-470. Retrieved from https://doi.org/10.1016/j.biotechadv.2008.05.003

Kavitha, M. (2016) Cold active lipases - an update, Frontiers in Life Science, Vol. 9, No.3, 226-238. Retrieved from https://doi.org/10.1080/21553769.2016.1209134

Kavitha, M., \& Shanthi, C. (2013) Isolation and Characterization of Cold active lipase producing Pseudomonas sp. 4 from Marine samples of Tamilnadu Coast, Research Journal of Biotechnology, Vol. 8, No. 4, 4-10.

Kuddus, M., \& Ramteke, P. W. (2008) Purification and properties of cold-active metalloprotease from Curtobacterium luteum and effect of culture conditions on production, Shengwu Gongcheng Xuebao/Chinese Journal of Biotechnology, Vol. 24, No. 12, 2074-2080. Retrieved from https://www.sciencedirect.com/science/article/abs/pii/S187220750960 0121

Kulakova, L., Galkin, A., Nakayama, T., Nishino, T., \& Esaki, N. (2004) Cold-active esterase from Psychrobacter sp. Ant300 : Gene cloning, characterization, and the effects of Gly $\rightarrow$ Pro substitution near the active site on its catalytic activity and stability, Biochimica et Biophysica Acta - Proteins and Proteomics, Vol. 1696, No. 1, 59-65. Retrieved from https://doi.org/10.1016/j.bbapap.2003.09.008

Mukesh, K., Rejitha, R., Devika, S., Balakumaran, M. D., Rebecca, I. N., \& Kalaichelvan, P. T. (2012) Production, optimization and purification of lipase from Bacillus sp. MPTK 912 isolated from oil mill effluent, Advances in Applied Science Research, Vol. 3, No. 2, 930-938. 
Rai, B., Shrestha, A., Sharma, S., \& Joshi, J. (2014) Screening, Optimization and Process Scale up for Pilot Scale Production of Lipase by Aspergillus niger, Biomedicine and Biotechnology, Vol. 2, No. 3, 54-59. Retrieved from https://doi.org/10.12691/bb-2-3-3

Santiago, M., Ramírez-Sarmiento, C. A., Zamora, R. A., \& Parra, L. P. (2016) Discovery, molecular mechanisms, and industrial applications of cold-active enzymes, Frontiers in Microbiology, 7, $1408 . \quad$ Retrieved from https://doi.org/10.3389/fmicb.2016.01408

Xuezheng, L., Shuoshuo, C., Guoying, X., Shuai, W., Ning, D., \& Jihong, S. (2010) Cloning and heterologous expression of two cold-active lipases from the Antarctic bacterium Psychrobacter sp. G, Polar Research, Vol. 29, No. 3, 421429. Retrieved from https://doi.org/10.3402/polar.v29i3.6087

Zhang, J. W., \& Zeng, R. Y. (2008) Molecular cloning and expression of a cold-adapted lipase gene from an antarctic deep sea psychrotrophic bacterium Pseudomonas sp. 7323, Marine Biotechnology, Vol. 10, No. 5, 2008, 612-621. Retrieved from https://doi.org/10.1007/s10126-008-9099-4 